\title{
ВПЛИВ ЗАНЯТЬ СПОРТОМ НА ФОРМУВАННЯ МАСКУЛІННИХ ТА ФЕМІНІННИХ РИС ХАРАКТЕРУ В ШКОЛЯРІВ РІЗНИХ ВІКОВИХ ГРУП
}

\author{
Тетяна Круцевич ${ }^{1}$, Оксана Марченко ${ }^{1}$ \\ ${ }^{1}$ Національний університет фізичного виховання і спорту України, Київ, o.mar4enko17@gmail.com
}

https://doi.org/10.29038/2220-7481-2020-01-74-89

\begin{abstract}
Анотації
Актуальність. У статті викладено різноманітні аспекти гендерної проблематики у фізичному вихованні школярів та досліджено актуальне питання щодо прояву гендерної ідентичності в учнів, які займаються й не займаються спортом. Завдання роботи - визначити вплив занять спортом на формування гендерних характеристик юнаків і дівчат різних вікових груп. Методи. Застосовано теоретичні методи дослідження: аналіз, порівняння, узагальнення, систематизація, теоретичне моделювання. Для дослідження вікових особливостей прояву психологічної статті використовували тест-опитувальник С. Бем «Маскулінність-фемінінність», факторний аналіз та загальноприйняті методи математичної статистики. У дослідженні взяли участь хлопці й дівчата 5-11 класів 33СО (638 особи). Результати роботи. Обгрунтовано актуальність обраної теми, проаналізовано та узагальнено дані вітчизняних і зарубіжних авторів щодо гендерної проблеатики у сфері фізичної культури й спорту. Одержано нові знання щодо впливу занять спортом на формування маскулінних рис характеру школярів. Виявлено, що в юнаків, які займаються спортом, на груповому рівні прояв властивостей маскулінності з віком посилюється на $50 \%$. Прояв ознак маскулінності на груповому рівні в дівчат, які займаються спортом, більше на $40 \%$, ніж у тих із них, які не займаються спортивною діяльністю. Із 303 юнаків 92,77 \% мають показник IS андогінного типу. Лише 5,12 \% юнаків репрезентують гендерну ідентичність маскулінного типу та $1 \%$ - характеристики фемінінного типу. Із-поміж 335 дівчат 73,89 \% віднесено до андрогінного типу особистості, 23,33 \% до фемінінного, маскулінні характеристики мають 2,78 \% дівчат. Виявлено наявність у юнаків жіночих рис характеру, а в дівчат - чоловічих. Це підтверджує максимальний розвиток фемінінного та маскулінного в одній людині, що сприятиме більшій соціальній адаптації школярів. Висновки. Отримані в результаті проведеного дослідження дані дали підставу зробити висновок про те, що заняття спортом сприяють розвитку певних маскулінних рис характеру. Причому більшою мірою це стосується представниць жіночої статі. Дівчата, які активно залучені до спортивної діяльності, є більш маскулінні за тих, котрі спортом не займаються. За допомогою добору ефективних засобів і методів фізкультурно-спортивної діяльності, орієнтації на вподобанні видів рухової активності в школярів закріплюються моделі поведінки та особистісні якості, що формують гендер. Отримані дані $є$ підставою для подальших поглиблених гендерних досліджень у сфері фізичної культури й спорту, результати яких стануть теоретичною основою концепції гендерного підходу у фізичному вихованні школярів.
\end{abstract}

Ключові слова: маскулінність, фемінніність, андрогінність, гендер, гендерна ідентичність, школярі, фізична культура, спорт.

Татьяна Круцевич, Оксана Марченко. Влияние занятий спортом на формирование маскулинных и фемининных черт характера у школьников разных возрастных групп. Актуальность. В статье рассматриваются различные аспекты гендерной проблематики и гендерного подхода в физическом воспитании школьников. Задачи работы - определение влияния занятий спортом на формирование гендерного типа личности юношей и девушек разных возрастных групп. Методы. Используются теоретические методы исследования: анализ, сравнение, обобщение, систематизация, теоретическое моделирование, тест-опросник Сандры Бем «Маскулинность-фемининность», факторний анализ и методы математической статистики. В исследовании приняли участие школьники 5-11 классов (638 человек). Результаты работы. Получены новые знания о влиянии занятий спортом на формирование маскулинных черт характера подростков. Подтверждается, что у юношей, занимающихся спортом, на групповом уровне проявление свойств маскулинности с возрастом усиливается на $50 \%$. Проявление признаков маскулинности на групповом уровне у девушек, занимающихся спортом, больше на 40 \%, по сравнению с теми, которые не занимаются спортивной деятельностью. Наблюдается специфичность проявления гендерной идентичности у школьников, которая определилась общим количеством респондентов, отнесенных к андрогинному типу личности. Из 303 юношей 92,77 \% имеют показатель IS андогинного типа, из 335 девочек 73,89 \% относятся к андрогинному типу личности, 23,33 \% - к фемининному, маскулинные характеристики имеють 2,78 \% девочек. Наблюдается наличие у юношей женских черт характера, а в девушек - мужских. Это подтверждает максимальное развитие фемининного и маскулинного в одном человеке, что способствует социальной адаптации школьников. Bbыводы. Полученные в результате проведенного 
исследования данные позволили сделать вывод о том, что занятия спортом способствуют развитию определенных маскулинных черт характера. Причем в большей степени это касается представительниц женского пола. Девушки, которые активно вовлечены в спортивную деятельность, больше маскулинные, чем те, которые спортом не занимаются. При помощи подбора эффективных средств и методов физкультурно-спортивной деятельности, ориентации на понравившиеся виды двигательной активности у школьников закрепляются модели поведения и личностные качества, формирующие гендер. Полученные данные являются основанием для дальнейших углубленных гендерных исследований в сфере физической культуры и спорта, результаты которых станут теоретической основой концепции гендерного подхода в физическом воспитании школьников.

Ключевые слова: маскулинность, феминниность, андрогинность, гендер, гендерная идентичность, школьники, физическая культура, спорт.

Tetiana Krutsevych, Oksana Marchenko. The Influence of Participating in Sports on Shaping Masculine and Feminine Character Traits of Schoolchildren of Different Age Groups. Topicality. The different aspects of gender problem and gender approach at pupils' physical education are considered in the research. Tasks of the Research. Gender identity manifestations of schoolchildren were investigated. An influence of participation in sports on shaping a gender personality type for young men and young women from different age groups was identified. The Research Methods. Theoretical methods of research were used: analysis, comparison, generalization, systematization, theoretical modeling. The questioner worked out by Sundry Bam «Masculinity-femininity» and methods of mathematical statistics were used. Pupils of 5-11 grades (638 pupils) took part in the researching. The Results of the Research. The knowledge of the influence of participation in sports on formation masculinity traits of teenagers' characters was taken. It was founded that for young men who participates in sports, on the group level, the occurrence of masculinity becomes bigger. It is $50 \%$ more than for men who do not participate in sports. The occurrence of masculinity, on the young women' group level, who participates in sport more than $30 \%$ in comparison with young women who do not participate in sports.

Conclusions. After the carried out study we drew a conclusion that practicing sport promotes the development of certain masculine characteristics. What is more it concerns female. It means that females who actively participate in sport are more masculine in comparison with those who do not. Due to effective approaches and methods of physical activity, orientation on motor activity, pupils are consolidated with patterns of behavior and personality qualities which shape the gender. Received data are the ground of the further and depth studying in the field of physical culture and sport, the results of which will become a theoretical ground of the conception of the gender approach at pupils' physical education.

Key words: pupils, gender differences, physical culture, sport, masculinity, femininity, androgenity.

Вступ. Головною метою освітньої політики щодо модернізації фізичного виховання молоді $\epsilon$ забезпечення нової якості навчання шляхом упровадження інноваційного змісту, форм i методів навчання школярів у сфері фізичної культури й спорту. На думку провідних українських учених Т. Ю. Круцевич, Н. В. Москаленко, Н. С. Пангелової, О. М. Томенко, О. Фащук, шкільна система фізичного виховання стане ефективною лише тоді, коли будуть створені максимально сприятливі умови для розкриття та розвитку фізичних, духовних і моральних якостей школярів [9; 11; 12; 22]. Система фізичного виховання має забезпечити кожній дитині повноцінний і гармонійний розвиток іiі здібностей, а також озброїти педагогів методиками особистісно зоріснтованого виховання.

Сьогодні гендерні дослідження потрібно розглядати не лише як напрям наукової думки, але і як освітню програму. Гендерні дослідження як навчальна програма, на думку І. Кльоциної, «спираються» на нову парадигму - концепцію гендерного підходу, в основу якої покладено розуміння гендеру як соціально сконструйованого відношення нерівності за статевою ознакою [9]. Вирішення питань, пов’язаних із феноменом статі, є важким не лише складністю та багатомірністю цієї проблеми, а й унаслідок недостатньої визначеності й однозначності термінів, які використовуються. Ключове поняття в гендерних дослідженнях - поняття «гендер» (gender). Цей термін уперше використано в 1968 р. психологом Р. Столлером, який установив залежність між розумінням чоловічих і жіночих ролей, між позиціями, рисами характеру й особливостями суспільного розвитку. Існування в англомовній літературі термінів «sex» i «gender», для яких у нашій мові немає аналогів, призвело до того, що трактування цих понять не є загальноприйнятими та вимагають авторського самовизначення. Під гендером розуміємо соціальну стать людини. Гендер визначаємо як сукупність соціальних і культурних норм, які в суспільстві, завдяки владі та домінуванню, приписують виконувати людям у зв'язку з їх статтю (С. Бем, 2004, с. 281) [3]. Термін «гендер» (gender) використовується в сучасних вітчизняних і західних гуманітарних дослідженнях для визначення статі як соціального терміна та явища на різницю від суто біологічної статі (sex). Стать (sex) є біологічною, а гендер - культурно-символічним визначенням статі. Дослідники вважають, що введення гендеру полягає в тому, щоб визначити стать продуктом людської культури. Прибічники гендерного підходу вважають, що дитина народжується 
чоловічої чи жіночої статі, але стає маскулінною або фемінінною в результаті виховання та процесу ідентифікації з гендерною роллю [1; 9]. Маскулінність і фемінінність (від лат. masculinus - чоловічий та femininus - жіночий) - нормативні уявлення про соматичні психічні й поведінкові властивості, які характерні для чоловіків та жінок (Психологічний словник, 1990).

Незважаючи на те, що гендерна тематика належить до нової сфери наукового знання й дуже повільно охоплює академічне середовище, існує достатня кількість науково-педагогічної літератури, яка, з огляду на свою значущість, може бути використана нами як науковий фундамент сучасних досліджень у галузі проблеми, що вивчається. Той факт, що чоловіки відрізняються від жінок не лише за фізіологічними характеристиками, але й за низкою психологічних рис характеру, відомо на рівні буденної свідомості вже досить довгий час. На сьогодні у світовій практиці нараховується понад 50000 робіт, у яких автори констатують наявність статевих відмінностей у різноманітних сферах онтогенезу людини [4]. Учені висловлюють думку, що за допомогою підбору засобів і методів фізкультурно-спортивної діяльності, орієнтації на види рухової активності, які подобаються, у школярів закріплюються моделі поведінки та особистісні якості, що формують гендер.

Аналіз документів, спостереження, матеріали анкетувань, аналіз наукової літератури є підставою, щоб стверджувати, що сучасний стан фізичної культури демонструє деякі суперечності у сфері гендерного підходу у фізичному вихованні загалом. Науковцями відзначено, що особливо гостро питання гендерної диференціації пов'язано з дійством (Б. Д. Ельконін 2001). Програма 3 фізичного виховання загальноосвітніх шкіл розрахована на середньостатистичну дитину й передбачає розвиток лише в тестових нормативах для хлопців і дівчат. Але, на жаль, не враховує гендерний підхід у формуванні особистості дитини, що може деформувати процес розвитку та негативно впливати на здоров'я [5].

Спільне виховання й навчання в школах В. Ф. Базарний (2005р.) називає безстатевим, відзначаючи протягом декількох поколінь зникнення з навчальних закладів статево-особистісної самоідентифікації молодих людей (особливо хлопчиків). Результатом цього стають пригніченість і нейтралізація чоловічих задатків у хлопців та жіночих - у дівчат, причому на генетичному рівні [3].

У теорії фізичної культури, як ні в одній іншій гуманітарній дисципліні, постійно враховуються природні основи статевих відмінностей. А численні дослідження в галузі спорту стосуються загалом статевого диморфізму ( С. Соха, 1991, Г. Соха, 1991; М. Меснер, 2000; Я. Шахліна, 2006; 2010; Maers A. M., Lips H. M., 1978). Проблемі гендерної освіти у своїх дослідженнях приділяли увагу такі науковці, як Здравомислова О. Л., Москальова А. С., Попова Л. В., Штильова Л. В.

Результати дослідження зарубіжних учених: T. Ryan, Y. Poirier, B. Murphy, R. A. Dionigi, C. Litchfield, C. S. Pawlowski, C. Ergler, T. Tjørnhø Thomsen, J. Schipperijn, K. L. Oliver, D. Kirk [21-29] свідчать про низький рівень теоретичних знань майбутніх фахівців сфери фізичного виховання щодо гендерних особливостей дітей, підлітків й учнівської молоді в процесі фізичного виховання. Саме тому в європейському освітньому просторі здійснюються ефективні крос-культурні дослідження проблем гендерної соціалізації та гендерного виховання молоді. Поліаспектне вивчення найкращих зразків зарубіжного досвіду у сфері гендерних питань сприятиме інтенсивнішій реалізації гендерного підходу у вітчизняну систему фізичного виховання, яка в Україні з різних причин розгортається надто повільно. Особливо значущим використання гендерного підходу $є$ серед учнів у підлітковому й старшому шкільному віці, коли відбувається перебудова всієї системи відносин людини 3 дійсністю, формується світогляд особистості та ії уявлення про власне призначення й сенс життя, а логіка психосоціального розвитку вимагає активного осмислення соціально вироблених способів поведінки [12].

Тому методологічною основою нашого дослідження є міждисциплінарний, крос-секторальний підхід щодо гендерної проблематики, який охоплює відповідні філософські, психолого-педагогічні, соціологічні, правові й інші аспекти до його розуміння. Наголошено на синкретичному поєднанні відомостей теорії та практики фізичної культури, педагогіки, психології в контексті організації навчання й виховання школярів у процесі їхньої гендерної соціалізації. Вищевикладене підтверджує актуальність проблеми, детермінує її вибір як теми наукового дослідження і $\epsilon$ підгрунтям для більш детального вивчення впливу рухової активності на формування гендерних характеристик школярів.

Роботу виконано відповідно до «Зведеного плану НДР у сфері фізичної культури і спорту на 20112015 рр.» Міністерства України у справах сім’ї, молоді та спорту за темою: 3.1 «Удсконалення програмно-нормативних основ фізичного виховання в навчальних закладах» (№ держреєстрації 0111U001733) та згідно з тематичним планом наукових досліджень і розробок, що виконуються за рахунок коштів державного бюджету МОН на 2016-2019 рр. за темою «Історичні та організаційно- 
методичні засади формування гендерного підходу у фізичному вихованні дітей, підлітків і молоді» шифр 1.2Ф. (№ державної реєстрації 0117U002386).

Мета дослідження - вивчення впливу спортом на формування гендерних характеристик хлопців та дівчат різних вікових груп.

Матеріал і методи дослідження. Для розв'язання поставлених завдань використовувався комплекс таких методів:

- теоретичні: аналіз, порівняння, узагальнення, систематизація, теоретичне моделювання проводили 3 метою узагальнення досвіду науковців, які займаються вивченням проблеми гендерного підходу в навчанні й вихованні, сучасних підходів до розвитку та вдосконалення системи фізичного виховання й визначення проблемного поля дослідження;

- психолого-діагностичні: опитувальник С. Бем «Маскулінність - фемінінність» (Bem Sex Role Inventori - BSRI)) використовувався для визначення індивідуальних гендерних характеристик школярів;

- загальноприйняті методи математичної статистики 3 розрахунком середніх арифметичних величин (х), середнього квадратичного відхилення (S), розраховувався коефіцієнт кореляції рангів Спірмена й проводився факторний аналіз, при якому застосовується метод головних компонент. Усі розрахунки виконувалися в програмі SPSS 17.0. Усі дані оброблялися на персональному комп'ютері 3 використанням пакета стандартних програм (Excel - 2007; Statistica - 10.0)

У науковому експерименті брали участь школярі 5-11 класів 33СО м. Полтави. Процедура наукових досліджень проводилася відповідно до етичних стандартів відповідального комітету з прав людини за погодженням управління освіти Полтавського міськвиконкому та письмової згоди директорів шкіл і батьків респондентів, що підтверджується відповідними документами.

Результати досліджуваних стратифікувалися відповідно до вікових періодів фізіологічного розвитку дітей і біологічної статі. Достовірність різниці між окремими результатами вираховувалася на рівні надійності $\mathrm{p}<0,05$ до $\mathrm{p}<0,01$, що свідчить про можливість їх урахування під час розробки практичних рекомендацій для вчителів фізичної культури, а також для подальших інтерпретацій.

Результати дослідження. Терміни «маскулінність» та «фемінінність» дають нормативні уявлення про психологічні й поведінкові якості, які характерні для чоловіків і жінок, які пов'язані з диференціацією статевих ролей. У людини статева диференціація соціально зумовлена [4]. Хлопці та дівчата традиційно відрізняються за характером діяльності: вони виконують різні статеві ролі. Розподіл цих ролей відбувається в дитинстві, він містить не лише ігри, звичайні для дітей різної статі, але й інші значущі відмінності між хлопцями та дівчатами. У 1974 р. Сандра Бем увела в психологію поняття андрогінії - поєднання високих показників за шкалою маскулінності з високими показниками за шкалою фемінінності. Запропонований тест фіксував маскулінність - фемінінність як незалежні виміри, що дало змогу описати чотири статево-рольові типи (маскулінний, фемінінний, андрогінний, недиференційований).

Фактор біологічної статі автоматично подвоює кількість визначених типів. Це слугувало основою для переходу від біологічної статі до психологічної; остання тлумачиться як ступінь виразності якостей і характеристик, властивих чоловічій та жіночій статтям.

Маскулінний тип характеризується найбільшою виразливістю таких якостей особистості, як незамінність, наполегливість, власність, схильність до захисту власних поглядів, до ризику, аналітичний склад мислення, віра в себе, самодостатність. Фемінінному типу особистості більшою мірою притаманні такі риси, як сором'язливість, ніжність, віддаленість, співчуття, здатність утішати, сердечність, м'якість, довірливість та любов до дітей. Андрогінному типу особистості приблизно однаковою мірою притаманні маскулінні й фемінінні якості особистості та риси характеру, що виявляються в поєднанні традиційно чоловічих і жіночих характеристик в одній людині [4; 12].

Запропонований C. Бем опитувальник (BSR) - один із найбільш використовуваних у науці інструментів для вимірювання того, як людина оцінює себе з погляду гендеру. Опитувальник містить 60 якостей характеру особистості, які стосуються стереотипів маскулінності, фемінінності й андрогінності.

Респондентам запропоновано оцінити наявність чи відсутність у себе зазначених рис. Основний індекс (IS) визначався за відповідною формулою. Спочатку, згідно з методикою С. Бем, ми розділили випробуваних на підгрупи за параметром «основний індекс» (IS) на фемінінних, маскулінних й андрогінних. Основний індекс IS розраховується за відповідною формулою. Величина індексу IS у 
межах від -1 до +1 свідчить про андрогінність, менша за -1 (IS <-1) - про маскулінність, більша від +1 (IS> +1) - про фемінінність [4].

Спочатку, відповідно до методики С. Бем, розділяємо випробуваних на підгрупи за параметром «основний індекс» (IS) на фемінінних, маскулінних та андрогінних. Результати дослідження представляємо в табл. 1; 2 .

Таблиия 1

Розподіл респондентів згідно з їх психологічним типом

(хлопці), $(\mathrm{n}=303)$

\begin{tabular}{|c|c|c|c|c|c|c|c|}
\hline \multirow{2}{*}{ Клас } & \multirow{2}{*}{$\begin{array}{c}\text { Кількість осіб } \\
\text { у класі }\end{array}$} & \multicolumn{2}{|c|}{$\begin{array}{c}\text { IS } \\
\text { маскулінного типу }\end{array}$} & \multicolumn{2}{|c|}{$\begin{array}{c}\text { IS } \\
\text { андрогінного типу }\end{array}$} & \multicolumn{2}{|c|}{$\begin{array}{c}\text { IS } \\
\text { фемінінного типу }\end{array}$} \\
\hline & & $\mathbf{n}$ & $\%$ & $\mathbf{n}$ & $\%$ & n & $\%$ \\
\hline 5-й & 21 & 0 & 2,00 & 20 & 98,00 & 0 & 0,00 \\
\hline 6-й & 50 & 2 & 4,00 & 47 & 94,00 & 1 & 2,00 \\
\hline 7-й & 34 & 0 & 0,00 & 33 & 97,06 & 1 & 2,94 \\
\hline 8-й & 55 & 3 & 5,45 & 51 & 92,73 & 1 & 1,82 \\
\hline 9-й & 90 & 6 & 6,67 & 82 & 91,11 & 2 & 2,22 \\
\hline 10-й & 12 & 0 & 0,00 & 12 & 100,00 & 0 & 0,00 \\
\hline 11-й & 41 & 5 & 12,20 & 34 & 82,93 & 2 & 4,88 \\
\hline Усього & 303 & 16 & 5,12 & 280 & 92,77 & 7 & 2.31 \\
\hline
\end{tabular}

Розподіл респондентів згідно з їх психологічним типом IS

Таблиия 2 (дівчата), $(\mathbf{n}=335)$

\begin{tabular}{|c|c|c|c|c|c|c|c|}
\hline \multirow{2}{*}{ Клас } & \multirow{2}{*}{$\begin{array}{c}\text { Кількість осіб } \\
\text { у класі }\end{array}$} & \multicolumn{2}{|c|}{\begin{tabular}{c}
\multicolumn{2}{c|}{ IS } \\
маскулінного типу
\end{tabular}} & \multicolumn{2}{c|}{$\begin{array}{c}\text { IS } \\
\text { андрогінного типу }\end{array}$} & \multicolumn{2}{c|}{ фемінінного типу } \\
\cline { 3 - 8 } & & $\mathbf{n}$ & $\%$ & $\mathbf{n}$ & $\mathbf{\%}$ & $\mathbf{n}$ & \% \\
\hline 5 -й & 53 & 0 & 0,00 & 43 & 80,77 & 10 & 19,23 \\
\hline 6-й & 54 & 2 & 5,56 & 42 & 77,78 & 9 & 16,67 \\
\hline 7 -й & 39 & 0 & 0,00 & 33 & 84,62 & 6 & 15,38 \\
\hline 8 8-й & 54 & 0 & 0,00 & 37 & 68,52 & 17 & 31,48 \\
\hline 9-й & 55 & 7 & 12,73 & 37 & 67,27 & 11 & 20,00 \\
\hline 10 -й & 15 & 0 & 0,00 & 11 & 73,33 & 4 & 26,67 \\
\hline 11 -й & 65 & 0 & 0,00 & 43 & 66,15 & 22 & 33,85 \\
\hline Усього & 335 & 10 & 2,78 & 246 & 73,89 & 79 & 23,33 \\
\hline
\end{tabular}

На підставі аналізу отриманих даних визначено, що більшість юнаків і дівчат, незалежно від віку, мають IS андрогінного типу особистості. Із 303 юнаків для 92,77 \% властивий показник IS андогінного типу. Лише 5,12 \% юнаків репрезентують гендерну ідентичність маскулінного типу та $1 \%$ характеристики фемінінного типу (табл. 1). Із-поміж 335 дівчат 73,89 \% віднесено до андрогінного типу особистості, 23,33 \% - до фемінінного, маскулінні характеристики мають 2,78 \% дівчат (табл. 2).

Загальні дані, отримані під час визначення основного індексу IS респондентів, та факт того, що більшість школярів належить до андрогінного типу особистості, породжують питання: «Які ж індивідуальні риси характеру й властивості особистості, котрі відображають стереотипи маскулінності- 
фемінінності, відзначають у своєму характері юнаки та дівчата різних вікових груп?» У зв'язку з цим проведено окремий аналіз індивідуальних якостей і рис характеру, які помітили в собі юнаки та дівчата. Проаналізуємо виокремлені під час тестування риси і якості характеру.

«Віра в себе»- риса характеру особистості, цілеспрямованої та впевненої у своїх силах. Таку якість побачили в собі, незалежно від віку, більше хлопців, ніж дівчат. Проте 96 \% дівчат 3- і 5-го класів та 83 \% 6-го помітили в собі цю рису характеру. Далі, із 7-го по 10-й клас, кількість дівчат, які виокремили якість «віра в себе», знижується. Привертає увагу те, що 100 \% юнаків, які займаються спортом, назвали цю якість. Різниця між юнаками й дівчатами становила $30-40 \%$ на користь юнаків.

«Сильна особистість» - якість, яку вчені відносять до маскулінних характеристик особистості. 60-70 \% хлопців 3- та 5-го класів указують на наявність у собі такої риси. «Наполегливість» - також маскулінна характеристика, яку помічають у собі на 15-20 \% більше юнаків, ніж дівчат. «Мужність» так само вважається суто чоловічою характеристикою. Відповідно, іiі простежили в собі від 80 до $100 \%$ юнаків. Цікаво, що 96,5 \% хлопців 3-го класу (вік 8 років) також підкреслили наявність у своєму характері такої якості. Проте зауважимо, що для дітей такого віку «мужність» є радше бажаною, ніж реально наявною якістю. На нашу думку, 8-річні хлопчики виокремлюють ії під впливом засвоєних статево-рольових стереотипів як властивість, обов'язково притаманну справжнім чоловікам, а не як уже сформовану в собі особистісну рису. Достовірність нашого припущення підтверджує й те, що школярі цієї вікової групи помічають у собі й таку характеристику, як «атлетичність». Так само 86,2% хлопців 3-го класу швидше прагнуть бути атлетично складеними та бажане приймають за дійсне. Насправді ж юнаки, які займаються атлетичною гімнастикою, ставляться до себе більш критично. Лише 68,7 \% виокремили в собі цю характеристику й насправді вважають себе атлетично складеними. Дівчата до атлетичності не виявили відповідної зацікавленості. Тільки 14,6 \% п’ятикласниць, які займаються спортом, відповіли, що мають таку якість. До 11-го класу відсоток «атлетичних» дівчат зменшився 3 16,6 до $13,3 \%$.

«Відданість» як властиву для себе характеристику більшою мірою виділили дівчата. Прикметно, що такою іiі позначили 96 \% третьокласниць і лише 46 \% дев'ятикласниць. Важливо, що 87,5\% юнаків (віком 17 років), які займаються атлетичною гімнастикою, назвали «відданість» рисою характеру, що їм притаманна. На 20 \% більше хлопців, порівняно з дівчатами, назвали властивою собі характеристику «аналітичні здібності». Суто маскулінні якості - «схильність до ризику» та «здібності до лідерства» також помічають у собі частіше хлопці, а не дівчата. Але досить значна кількість дівчат (56 \%) у 3-му класі, 35,7 \% - у 5-му, 41 \% - у 6-му, 46 \% - в 11-му вбачали в собі «здібність до лідерства». Також від 40 до 60 \% дівчат 5-, 6-, 7-, 10- та 11-го класів обрали «схильність до ризику» однією з важливих якостей свого характеру. Із різницею в 10-15 \% «життєрадісність» позначається частіше хлопцями. «Любов до дітей» помітили в собі більше дівчат, ніж хлопців і юнаків. Проте така різниця невелика. Наприклад, 5-й клас - 60 \% хлопців та 71,4 \% дівчат; 6-й клас - 73,9 \% хлопців і 88,2 \% дівчат. Надалі відсоток респондентів, котрі позначили «любов до дітей» як властиву собі рису, знижуються і в юнаків, і в дівчат. Наприклад, учні 9-го класу - 47,3 \% хлопців та 57,6 \% дівчата; 10 -го класу - 58,3 \% хлопців і $73,3 \%$ дівчат.

Виявлено, що значна кількість юнаків підкреслила наявність у собі психологічних характеристик, які традиційно вважаються жіночими. Зокрема, «сором'язливість» виділили 33 \% у 5-му, 62 \% - у 7-му, 59 \% - у 8-му класах. Далі з віком відсоток юнаків, які назвали «сором'язливість» властивою їм рисою, знизився. «Ніжність» як притаманну собі рису позначили 62 \% хлопців 3-го класу, 53,9 \% - 5-го, 53 \% 7-го, $81 \%$ - 8-го класу, $64 \%$ - 11-го. Зауважимо, що 87,5\% юнаків, які займаються атлетичною гімнастикою, помітили у своєму характері «відданість». Зі свого боку, чимало дівчат позначили як властиві їм ті якості, що традиційно належать до чоловічих. Зокрема, «здатність до лідерства» та «аналітичні здібності» відзначили в себе 41,0 \% шестикласниць і 46,0 \% випускниць, а «схильність до ризику» - дівчата 5-, 6-, 7-, 10- й 11-го класів (40-60 \% від загальної кількості школярок).

Отримані дані дають підставу констатувати наявність у юнаків та дівчат одночасно маскулінних і фемінінних характеристик. Цей факт підтверджується загальною кількістю респондентів, які, згідно 3 отриманими результатами тестування, віднесені до андрогінного типу особистості Тобто, з одного боку, суто маскулінні якості помічають у собі частіше юнаки, а фемінінні - дівчата. Проте їхні відповіді можуть бути результатом статево-рольового виховання в школі, яке формує визначену стереотипну поведінку хлопців і дівчат. 3 другого боку, хлопці та юнаки помічають у собі фемінінні якості, а дівчата - маскулінні. Це дає нам підставу говорити про наявність в одній людині одночасно 
маскулінних і фемінінних якостей, що підтверджує достовірність концепції андрогінії, запропонованої на початку 1970-х рр. американським психологом С. Бем.

Наступний крок у нашому науковому дослідженні для отримання більш детальної інформації аналіз запропонованих під час тестування якостей на груповому рівні (табл. 3).

Таблиия 3

Динаміка прояву ознак маскулінності в юнаків за віковими періодами, $(\mathrm{n}=\mathbf{3 0 3}), \%$

\begin{tabular}{|c|c|c|c|c|}
\hline \multirow{2}{*}{$\begin{array}{c}\text { № } \\
\text { 3/II }\end{array}$} & \multirow{2}{*}{ Маскулінна якість } & \multicolumn{3}{|c|}{ Віковий період } \\
\hline & & 11-13 років & 14-15 років & 16-17 років \\
\hline \multicolumn{5}{|c|}{ Збілышуються з віком } \\
\hline 1 & Здатність захищати свої погляди & 63,16 & 68,60 & 83,02 \\
\hline 2 & Незалежність & 60,53 & 53,49 & 64,15 \\
\hline 3 & Наполегливість & 47,37 & 45,35 & 62,26 \\
\hline 4 & Здатність до ризику & 78,95 & 53,49 & 79,25 \\
\hline 5 & Самодостатність & 34,21 & 46,51 & 64,15 \\
\hline 6 & Власна позиція & 50,00 & 46,51 & 73,58 \\
\hline 7 & Сила & 73,68 & 73,26 & 75,47 \\
\hline 8 & Амбітність та честолюбство & 28,95 & 31,40 & 33,96 \\
\hline 9 & Індивідуалізм & 39,47 & 47,67 & 58,49 \\
\hline \multicolumn{5}{|c|}{ Слабовиражені або знижуються з віком } \\
\hline 1 & Вipa в себе & 89,47 & 74,42 & 77,36 \\
\hline 2 & Атлетичність & 57,89 & 54,65 & 60,38 \\
\hline 3 & Сильна особистість & 47,37 & 51,16 & 49,06 \\
\hline 4 & Аналітичні здібності & 44,74 & 40,70 & 47,17 \\
\hline 5 & Здатність до лідерства & 65,79 & 52,33 & 49,06 \\
\hline 6 & Швидкість прийняття рішень & 73,68 & 45,35 & 54,72 \\
\hline 7 & Мужність & 89,47 & 65,12 & 77,36 \\
\hline 8 & Дух змагання & 63,16 & 56,98 & 67,92 \\
\hline 9 & Власність & 21,05 & 27,91 & 26,42 \\
\hline 10 & Агресивність & 26,32 & 25,58 & 37,74 \\
\hline 11 & Здатність вести за собою & 50,00 & 38,37 & 47,17 \\
\hline
\end{tabular}

Динаміка прояву ознак маскулінності в дівчат

Табличя 4 за віковими періодами, $(\mathrm{n}=335), \%$

\begin{tabular}{|c|c|c|c|c|c|}
\hline \multirow{2}{*}{$\begin{array}{c}\text { № } \\
\text { 3/II }\end{array}$} & \multirow{2}{*}{ Маскулінна якість } & \multicolumn{4}{|c|}{ Віковий період } \\
\hline & & & 11-13 років & 14-15 років & 16-17 років \\
\hline 1 & 2 & 3 & 4 & 5 & 6 \\
\hline \multicolumn{6}{|c|}{ Збільшуються з віком } \\
\hline 1 & Здатність захищати свої погляди & & 65,52 & 53,57 & 67,50 \\
\hline 2 & Здатність до ризику & & 48,28 & 42,86 & 52,50 \\
\hline 3 & Власна позиція & & 24,14 & 46,43 & 55,00 \\
\hline 4 & Індивідуалізм & & 41,38 & 44,64 & 55,00 \\
\hline 5 & Самодостатність & & 17,24 & 37,50 & 46,25 \\
\hline 6 & Амбітність та честолюбство & & 31,03 & 32,14 & 47,50 \\
\hline \multicolumn{6}{|c|}{ Знижуються з віком } \\
\hline 1 & Вipa в себе & & 93,10 & 53,57 & 73,75 \\
\hline 2 & Атлетичність & & 31,03 & 23,21 & 12,50 \\
\hline 3 & Сила & & 62,07 & 41,07 & 38,75 \\
\hline 4 & Швидкість прийняття рішень & & 48,28 & 46,43 & 41,25 \\
\hline 5 & Мужність & & 20,69 & 21,43 & 17,50 \\
\hline 6 & Дух змагання & & 34,48 & 32,14 & 40,00 \\
\hline 7 & Незалежність & & 44,83 & 51,79 & 46,25 \\
\hline 8 & Наполегливість & & 37,93 & 32,14 & 41,25 \\
\hline 9 & Сильна особистість & & 44,83 & 57,14 & 41,25 \\
\hline 10 & Аналітичні здібності & & 37,93 & 28,57 & 23,75 \\
\hline
\end{tabular}


Закінчення табличі 4

\begin{tabular}{|c|l|c|c|c|c|}
\hline $\mathbf{1}$ & \multicolumn{1}{|c|}{$\mathbf{2}$} & $\mathbf{3}$ & $\mathbf{4}$ & $\mathbf{5}$ & $\mathbf{6}$ \\
\hline 11 & Здатність до лідерства & & 37,93 & 39,29 & 33,75 \\
\hline 12 & Власність & & 17,24 & 19,64 & 11,25 \\
\hline 13 & Здатність вести за собою & & 34,48 & 28,57 & 35,00 \\
\hline 14 & Агресивність & & 20,69 & 26,79 & 22,50 \\
\hline
\end{tabular}

Аналіз прояву властивостей маскулінності в дівчат доводить, що на груповому рівні 3 віком посилюється прояв таких психологічних характеристик (6 із 20): захищати власні погляди (iз 47,17 до 67, $50 \%$ ), самодостатність (із 32,08 до 46,25 \%), здатність до ризику (із 30,19 до $52,50 \%$ ), власна позиція (із 35,85 до 55,0 \%), індивідуалізм (із 33,96 до 55,0 \%), амбітність та честолюбство (із 24,53 до $47,50 \%$ ), агресивність (із 16,98 до 22,50 \%) (табл. 4). Також відзначається зниження прояву таких якостей, які вважаються головними ознаками маскулінності (14 із 20): віра в себе (із 96,23 до 73,75 \%), атлетичність (із 62,23 до 12,50 \%), сила (із 58,49 до 38,75 \%), аналітичні здібності (із 49,06 до 23,75 \%), здатність до лідерства (із 45,28 до 33,75 \%), мужність (із 62,2 до 17,5 \%), швидкість прийняття рішень (iз 64,15 до $41,25 \%$ ) та дух змагань (із 54,72 до 52,0 \%).

Отже, нами з'ясовано, що з віком ознак маскулінності в юнаків стає більше, ніж у дівчат. Згідно 3 отриманими результатами нашого дослідження (методика Сандри Бем «Маскулінність - фемінінність»), юнаки, які займаються спортом, належать до таких типів особистості: 91,86 \% - до андрогінного, 5,81\% - до маскулінного, 2,33 \% - до фемінінного. Натомість маскулінні характеристики мають 27,3\% дівчат-спортсменок, що, відповідно, більш ніж на $20 \%$ перевищує кількість юнаків, які займаються спортом. Фемінінному типу відповідають 13,6 \% дівчат, андрогінному - 59,1\%. Усі опитані нами дівчата, які займаються тхеквондо, мають маскулінний тип характеру.

Окремий аналіз індивідуальних рис та якостей характеру, які відзначили в собі спортсмени, дав підставу отримати більш детальну інформацію про вплив спортивної діяльності на формування психологічних рис характеру школярів. За результатами відповідей юнаків і дівчат можна простежити вибір спортсменами переважно маскулінних характеристик, але водночас констатувати більш критичне ставлення до власної статури в юнаків, які займаються атлетичною гімнастикою. Важливо вказати, що спортсмени обирали не лише маскулінні характеристики. Наприклад, 87,5 \% юнаків, які займаються атлетичною гімнастикою, назвали як властиву своєму характеру якість «відданість», що є більш жіночою. Традиційно вважається, що вживання в спілкуванні «міцного слова», тобто вульгарної, грубої лексики - прерогатива чоловіків. Проте результати дослідження засвідчують, що серед дівчат лише 5,88 \% негативно ставляться до вживання так званих нецензурних висловлювань, а 17,65 \% вважають послугування ними цілком прийнятним. Крім того, лише 5,8 \% дівчат-спортсменок помітили в собі такі фемінінні характеристики, як «сором'язливість», «скритність» та «відданість». Проте 29,41% спортсменок не знаходять у собі таких якостей.

Дівчата, які займаються спортивною діяльністю, є більш маскулінні в психологічному плані, ніж ті, які спортом не займаються. Їх відрізняє більш висока самооцінка низки якостей, які зазвичай асоціюються з мужністю, розвиненою волею та більш високою агресивністю. У спортсменів чоловічої статі меншою мірою проявляються фемінінні характеристики особистості. Рівень прояву емпатії до навколишніх і комунікативні характеристики також більшою мірою виражені в дівчат та юнаків, котрі займаються спортом. Серед тхеквондистів тенденція до маскулінності характерна більшою мірою для дівчат, ніж для юнаків. За результатами, отриманими під час тестування респондентів за методикою С. Бем, лише 5,81 \% юнаків, які займаються спортом, мають маскулінні характеристики, фемінінні $2,33 \%$ респондентів, андрогінний тип особистості мають $91,86 \%$ спортсменів. Серед дівчатспортсменок маскулінні характеристики мають 27,3\%. Це більше на $20 \%$, порівняно 3 кількістю маскулінних юнаків-спортсменів. Фемінінному типу відповідають 13,6 \% дівчат, котрі займаються спортом, андрогінному - 59,1%. Дівчата, які займаються тхеквондо, мають маскулінний тип характеру $(100 \%)$.

Як уже зазначено, отримані за методикою С. Бем дані, для нас не були інформативними. У зв'язку 3 цим зроблено детальний аналіз запропонованих під час тестування якостей та рис характеру, визначених спортсменами на груповому рівні. Результати представлено в табл. 5, 6 . 
Динаміка прояву ознак маскулінності в хлопців, які займаються спортом, (n=97), \%

\begin{tabular}{|c|c|c|c|}
\hline \multirow{2}{*}{ № } & \multirow{2}{*}{ Маскулінна якість } & \multicolumn{2}{|c|}{ Віковий період } \\
\hline & & 14-15 років & 16-17 років \\
\hline \multicolumn{4}{|c|}{ Збільшуються з віком } \\
\hline 1 & Віра в себе & 78,26 & 92,50 \\
\hline 2 & Здатність захищати свої погляди & 76,09 & 82,50 \\
\hline 3 & Незалежність & 47,83 & 62,50 \\
\hline 4 & Атлетичність & 54,35 & 62,50 \\
\hline 5 & Наполегливість & 47,83 & 65,00 \\
\hline 6 & Сильна особистість & 50,00 & 52,00 \\
\hline 7 & Сила & 71,74 & 77,50 \\
\hline 8 & Здатність до ризику & 54,35 & 85,00 \\
\hline 9 & Швидкість у прийнятті рішень & 39,13 & 50,00 \\
\hline 10 & Самодостатність & 56,52 & 67,50 \\
\hline 11 & Мужність & 58,70 & 77,50 \\
\hline 12 & Власна позиція & 47,83 & 77,50 \\
\hline 13 & Індивідуалізм & 58,70 & 65,00 \\
\hline 14 & Дух змагання & 56,52 & 65,00 \\
\hline 15 & Агресивність & 32,61 & 42,50 \\
\hline \multicolumn{4}{|c|}{ Слабо визначені або знижуються з віком } \\
\hline 1 & Аналітичні здібності & 45,65 & 47,50 \\
\hline 2 & Здатність до лідерства & 56,52 & 47,50 \\
\hline 3 & Власність & 23,91 & 25,00 \\
\hline 4 & Здатність вести за собою & 45,65 & 47,50 \\
\hline 5 & Амбіційність, честолюбство & 39,13 & 35,00 \\
\hline
\end{tabular}

Отже, у хлопців, які займаються спортом, на груповому рівні прояв властивостей маскулінності з віком посилюється за 15 із 20 позицій (табл. 5). Це більше ніж $50 \%$, порівняно з юнаками, які не займаються спортом. У дівчат, котрі займаються спортом, прояв властивостей маскулінності 3 віком посилюється за 15-ма позиціями із 20-ти (табл. 6). Це такі риси характеру, як віра в себе (із 78,26 до 92,50 \%), здатність захищати свої погляди (із 76,09 до 82,50 \%), незалежність (із 47,83 до $65,0 \%$ ), наполегливість (47,83 до 65,0 \%), сильна особистість (із 50,0 до 52,2 \%), здатність до ризику (iз 54,25 до 85,0 \%), самодостатність (із 56,52 до 67,5 \%), власна позиція (із 47,83 до 77,5 \%), атлетичність (із 54,35 до 62,5 \% ), індивідуалізм (із 58,7 до 65,0 \%), дух змагань (із 56,52 до 65,0 \%), наполегливість (із 47,83 до 62,5 \% ), швидкість у прийнятті рішень (із 39,13 до 55,0 \%) та мужність (із 58,7 до 77,5 \%). За результатами нашого дослідження, що прояв ознак маскулінності в дівчат, які займаються спортом, більший на 30 \%, порівняно з тими респондентками, які не займаються спортивною діяльністю.

Також відзначимо той факт, що суто маскулінні якості особистості на 20-40 \% більше простежують юнаки, ніж дівчата, а суто жіночі якості - на 40 \% більше дівчата.

Отримані в результаті проведеного дослідження дані дали підставу зробити висновок про те, що заняття спортом сприяють розвитку певних маскулінних рис характеру. Причому більшою мірою це стосується представниць жіночої статі. Дівчата, які активно залучені до спортивної діяльності, $є$ більш маскулінні, ніж ті, які спортом не займаються. Їх вирізняє вища самооцінка низки якостей, які зазвичай асоціюються з мужністю, розвиненою волею й більш високою агресивністю. У спортсменів чоловічої статі менше проявляються фемінінні характеристики особистості. Рівень прояву емпатії до оточення та комунікативні характеристики більше виражені в дівчат і юнаків, котрі займаються спортом. 
Динаміка прояву ознак маскулінності в дівчат, які займаються спортом, $(\mathrm{n}=29), \%$

\begin{tabular}{|c|c|c|c|}
\hline \multirow{2}{*}{$\begin{array}{l}\text { № } \\
\text { 3/II }\end{array}$} & \multirow{2}{*}{ Маскулінна якість } & \multicolumn{2}{|c|}{ Віковий період } \\
\hline & & 14-15 років & 16-17 років \\
\hline \multicolumn{4}{|c|}{ Збільшуються з віком } \\
\hline 1 & Віра в себе & 53,57 & 73,75 \\
\hline 2 & Здатність захищати власнї погляди & 53,57 & 67,50 \\
\hline 3 & Здатність до ризику & 42,86 & 52,50 \\
\hline 4 & Власна позиція & 46,43 & 55,00 \\
\hline 5 & Індивідуалізм & 44,64 & 55,00 \\
\hline 6 & Наполеглевість & 32,14 & 41,25 \\
\hline 7 & Самодостатність & 37,50 & 46,25 \\
\hline 8 & Здатність вести за собою & 28,57 & 35,00 \\
\hline 9 & Дух змагання & 32,14 & 40,0 \\
\hline 10 & Амбіційність, чистолюбство & 32,14 & 47,50 \\
\hline \multicolumn{4}{|c|}{ Знижуються з віком } \\
\hline 1 & Незалежність & 51,79 & 46,25 \\
\hline 2 & Сильна особистість & 57,14 & 41,25 \\
\hline \multicolumn{4}{|c|}{ Слабовизначені } \\
\hline 1 & Атлетичність & 23,21 & 12,50 \\
\hline 3 & Сила & 41,07 & 38,75 \\
\hline 4 & Аналітичні здібності & 28,57 & 23,75 \\
\hline 5 & Здатність до лідерства & 39,29 & 33,75 \\
\hline 6 & Швидкість прийняття рішень & 46,43 & 41,25 \\
\hline 8 & Власність & 19,64 & 11,25 \\
\hline 9 & Мужність & 21,43 & 17,50 \\
\hline 10 & Агресивність & 26,79 & 22,50 \\
\hline
\end{tabular}

Аналітичний аналіз отриманих даних дав нам підставу також виділити індивідуальні психологічні характеристики особистості, які більшою мірою притаманні школярам, які не займаються спортом. Для юнаків - це показники, які практично не були названі: ніжність, теплота, щедрість, співчуття, турбота про людей, м'якість, жіночність, здатність допомагати, уміння поступатися, здатність співчувати, розуміння інших, уміння втішати, життєрадісність, надійність, віра в себе, прямота. Для дівчат - це такі психологічні характеристики, як довірливість, уміння дружити, любов до дітей і спокій, відзначено лише в 5,8 \% респонденток. 11,\% спортсменок проігнорували вищезазначені якості. Тільки 5,88 \% дівчат, які займаються спортом, відзначили «нелюбов до лайок», натомість 17,65 \% вважають для себе цю характеристику абсолютно прийнятою. Лише 5,8 \% дівчат-спортсменок назвали в собі риси характеру, які вчені відносять здебільшого до фемінінних характеристик особистості: «сором'язливість», «потайність», «відданість». 29,41 \% спортсменок не відзначають у собі таких якостей. За результатами нашого дослідження виявлено, що серед тхеквондистів тенденція до маскулінності більше властива дівчатам, ніж юнакам.

Дослідивши характерні особливості прояву ознак психологічної статі школярів, їхні особливості та відмінності в гендерному аспекті, визначивши характерні відмінності цих показників у спортсменів, наступним етапом у вивченні гендерної ідентичності школярів, які займаються й не займаються спортом, було встановлення динаміки прояву характерних гендерних ознак юнаків і дівчат за віковими періодами (табл. 7).

Наступним етапом нашого експерименту було проведення факторного аналізу показників психологічних характеристик. Розрахунки здійснювали в пакеті SPSS 17.0. За результатами факторного аналізу показників тестування юнаків ми отримали чотири найбільш значущі фактори (табл. 8). 
Динаміка прояву характерних гендерних ознак школярів за віковими періодами

(кількість ознак), $(\mathrm{n}=638)$

\begin{tabular}{|c|c|c|c|c|}
\hline \multirow{2}{*}{$\begin{array}{c}\text { Гендерна } \\
\text { ознака (ви- } \\
\text { ще за } 50 \text { \%) }\end{array}$} & \multirow{2}{*}{ Стать } & \multicolumn{3}{|c|}{ Вік } \\
\hline & & 11-13 років & 14-15 років & 16-17 років \\
\hline \multirow{4}{*}{ 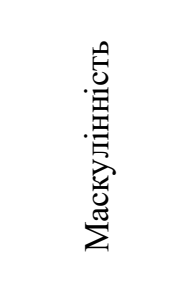 } & Юнаки & 12 & 10 & 13 \\
\hline & Юнаки, які займаються спортом & - & 11 & 14 \\
\hline & Дівчата & 7 & 4 & 5 \\
\hline & Дівчата, які займаються спортом & - & 4 & 5 \\
\hline \multirow{4}{*}{ 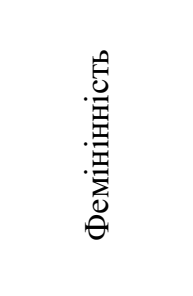 } & Юнаки & 15 & 11 & 12 \\
\hline & Юнаки, які займаються спортом & - & 8 & 13 \\
\hline & Дівчата & 12 & 11 & 16 \\
\hline & Дівчата, які займаються спортом & - & 9 & 13 \\
\hline \multirow{4}{*}{ 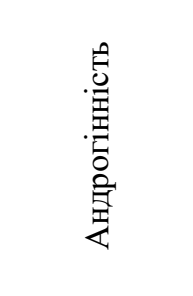 } & Юнаки & 9 & 7 & 11 \\
\hline & Юнаки, які займаються спортом & - & - & - \\
\hline & Дівчата & 9 & 8 & 12 \\
\hline & Дівчата, які займаються спортом & - & - & - \\
\hline Усього & & 68 & 83 & 114 \\
\hline
\end{tabular}

Провідні фактори гендерних ознак юнаків

\begin{tabular}{|c|l|c|c|}
\hline $\begin{array}{c}\text { № } \\
\text { 3/п }\end{array}$ & \multicolumn{1}{|c|}{ Фактор } & $\begin{array}{c}\text { Дисперсійний } \\
\text { внесок, \% }\end{array}$ & $\begin{array}{c}\text { Загальний } \\
\text { внесок, \% }\end{array}$ \\
\hline I & $\begin{array}{l}\text { Ніжність (0,733), щирість (0,582), теплота (0,727), м’якість } \\
(0,541)\end{array}$ & 14,66 & 49,67 \\
\hline II & $\begin{array}{l}\text { Атлетичність (0,533), сильна особистість (0,534), сила } \\
(0,794)\end{array}$ & 5,68 & 19,23 \\
\hline III & $\begin{array}{l}\text { Здатність допомогти (0,679), уміння співчувати (0,599), } \\
\text { уміння дружити (0,717) }\end{array}$ & 5,41 & 18,31 \\
\hline IV & $\begin{array}{l}\text { Совісність (0,640), співчуття (0,557), тактовність (0,678), } \\
\text { амбіційність (0,532) }\end{array}$ & 3,77 & 12,79 \\
\hline & \multicolumn{1}{|c}{ Усього } & 29,52 & 100,00 \\
\hline
\end{tabular}

1-й фактор об'єднав риси характеру, які засвідчують рівень прояву доброти й щирості до людей, а саме: привабливість, ніжність, теплота, щирість, м'якість. Ці психологічні характеристики відносять до фемінінних. 17,5 \% юнаків відзначили в собі вищевказані риси характеру, які ввійшли в 1-й фактор. Чи не проявилися ці риси особистості у 23,3 \% юнаків-спортсменів. Отже, можемо відзначити, що в спортсменів меншою мірою проявляються фемінінні характеристики особистості.

2-й фактор об'єднав маскулінні риси характеру (мужність, сила, сильна особистість) й атлетичного. Цей фактор яскраво виражений усього лише в 11,2\% юнаків, не прийняли його - 18,5 \% респондентів. Між вибірками спортсменів і юнаками, які спортом не займаються, цих якостей не виявлено.

3-й фактор об'єднав характеристики, що визначають рівень прояву емпатії до оточення: уміння дружити, здатність допомогти, уміння співчувати, уміння поступатися, відданість, Ці психологічні 
характеристики відзначили 10,2 \% юнаків. 17 \% респондентів заперечують наявність цих характеристик у своєму характері, у спортсменів, які займаються - 11,3 проти 9,2\%).

4-й фактор об'єднав характеристики, які визначають, найімовірніше, комунікативні якості характеру: тактовність, совісність, співчуття, амбітність, адаптивність, індивідуалізм, життерадісність, любов до дітей. Це яскраво виражено у 21,8 \% юнаків. Більшою мірою такі психологічні характеристики відзначено в спортсменів (28,2 проти 18,5\%).

У результаті факторного аналізу 60-ти показників опитувальника С. Бем у дівчат також виявлено чотири найбільш значущі фактори (табл. 9).

Значущі фактори гендерних ознак дівчат

\begin{tabular}{|c|l|c|c|}
\hline $\begin{array}{c}\text { № } \\
\text { 3/п }\end{array}$ & \multicolumn{1}{|c|}{ Фактор } & $\begin{array}{c}\text { Дисперсійний } \\
\text { внесок, \% }\end{array}$ & $\begin{array}{c}\text { Загальний } \\
\text { внесок, \% }\end{array}$ \\
\hline I & $\begin{array}{l}\text { Здатність допомогти (0,562), життєрадісність (0,503), } \\
\text { уміння співчувати (0,741), розуміння інших (0,550), } \\
\text { здатність утішати (0,776) }\end{array}$ & 13,70 & 45,38 \\
\hline II & $\begin{array}{l}\text { Теплота (0,602), м’якість (0,698), уміння дружити (0,607), } \\
\text { довірливість (0,698), любов до дітей (0,640) }\end{array}$ & 7,31 & 24,19 \\
\hline III & $\begin{array}{l}\text { Незалежність (0,537), ласий до лестощів (0,678), } \\
\text { традиційність (0,632) }\end{array}$ & 5,03 & 16,65 \\
\hline IV & Сильна особистість (0,538), здатність до лідерства (0,739) & 4,16 & 13,78 \\
\hline & Усього & 30,20 & 100,00 \\
\hline
\end{tabular}

1-й фактор об'єднав у собі риси характеру, що визначають рівень емпатії до навколишніх: здатність утішити, співчуття, здатність прийти на допомогу, розуміння інших, життєрадісність, співчуття, турбота про людей, надійність, віра в себе. Наявність вищевказаних характеристик відзначили в себе всього $8 \%$ респонденток. Відсутні ці характеристики в $16 \%$ дівчат. Рівень прояву емпатії до навколишніх більшою мірою виражений у дівчат, які займаються спортом (23,5 проти 6,6 \%).

2-й фактор містить лише фемінінні характеристики: довірливість, м'якість, любов до дітей, дружба, теплота, спокій, жіночність. 10,8 \% дівчат зазначили такі риси у своєму характері. Цікавий факт, що 29,4 \% дівчат, які займаються спортом, не бачать себе вищевказаних рис характеру. Це свідчить про те, що дівчатам, які не займаються спортивною діяльністю, характерний більш високий рівень фемінінності, ніж спортсменкам.

3-й фактор засвідчує рівень амбіцій людини й об’єднує в собі такі якості характеру, як бажання лестощів, традиційність, марнославство, незалежність та атлетичність. Ці психологічні характеристики більш маскулінні й переважають у дівчат, які займаються спортом (23,5 проти 19,4%).

4-й фактор об'єднує в собі якості сильної особистості: здатність до лідерства, сильна особистість і дух змагань. Такі риси характеру також більшою мірою притаманні дівчатам, котрі займаються спортивною діяльністю (23,5 проти 18,9 \%).

Отже, факторний аналіз засвідчив, що прояв фемінінності й маскулінності школярів детерміновані особливостями їхньої діяльності, у цьому випадку ми говоримо про заняття спортом. Згідно з аналізом прояву гендерних ознак у юнаків і дівчат, за результатами факторного аналізу можемо припустити, що деякі з них є лімітуючими в поведінці статевих груп.

Так, у юнаків потребує уваги виховання таких комунікативних якостей, як щирість у відносинах, доброта й відвертість (вплив до 50 \%). Хоча вищезазначені риси С. Бем відносить до фемінінних, однак для адаптації мікросередовища сучасним школярам їх не вистачає. Те ж саме стосується й структури гендерних особливостей і дівчат. Серед виділених 4-х факторів у юнаків три так чи інакше об'єднують соціальні й комуникативні риси (ставлення навколишніх, здатність допомогти, уміння дружити, співчуття, тактовність). Мінімальний прояв цих психологічних якостей у підлітків і $є$ свідченням їхньої агресивної поведінки з однолітками, що відзначається педагогами та психологами. До 20 \% виховного впливу потребує формування маскулінних ознак, таких як атлетичність, сила, сильна особистість, які більшою мірою проявляються в тих, хто займається спортом. Звертає на себе увагу структура факторів у дівчат. 3- і 4-й фактори об'єднують маскулінні ознаки (загалом 30 \%), які в дівчат виражені меншою мірою. Із погляду статево-рольового підходу до виховання школярок, можемо припустити, що для їх адаптації до мікросередовища й соціалізації не вистачає прояву амбітності, сильної особистості, 
здатності до лідерства, що можна віднести більшою мірою до маскулінних ознак. На нашу думку, вихованню вищевказаних психологічних якостей сприяють заняття спортом.

Дискусія. Отже, незважаючи на низку критичних зауважень щодо концепції андрогінії, вона зберігає своє значення та використовується в подальших дослідженнях, у тому числі й в Україні. На сьогодні такі ідеї, як поєднання фемінінних і маскулінних рис характеру в одній людині, популяризується в науці. Це підтверджується загальною кількістю школярів, віднесених до андрогінного типу особистості. Також потрібно відзначити той факт, що суто маскулінні риси особистості на 20-40\% більше відзначають юнаки, ніж дівчата, а суто жіночі риси - на 40 \% більше дівчата. Науковці довели, що маскулінність, андрогінність, фемінінність як психологічні характеристики особистості формуються в процесі соціалізації згідно з нормативними конструктами для хлопців і дівчат, а їх прояв $є$ важливим компонентом гендерної ідентичності особистості [3]. Учені наголошують, що гендерна соціалізація, у процесі якої відбувається становлення гендерної ідентичності особистості, триває протягом усього життя людини [6; 8; 9; 12]. Дослідниці Л. Н. Слєпова та Т. Н. Хаірова висловлюють слушну думку про те, що людина відкриває фізичну культуру не стільки для себе, скільки відкриває себе у світі фізичної культури [16]. Від своєчасності та повноти сформованості психологічних рис чоловічості й жіночності багато в чому залежать упевненість у собі, цільність переживань, визначеність установок, що в майбутньому впливатимуть на ефективність спілкування з людьми, на стосунки в сім'ї та колективі [13]. Агентами соціалізації дослідники вважають сім'ю, батьків, школу, друзів, однолітків, ЗМІ. На нашу думку, фізична культура й спорт, безперечно, є одними із суттєвих засобів гендерної соціалізації школярів. За допомогою добору ефективних засобів і методів фізкультурно-спортивної діяльності, орієнтації на вподобані види рухової активності в школярів закріплюються моделі поведінки та особистісні якості, що формують гендер.

Учені, які займаються гендерною проблематикою, активно студіюють питання впливу занять спортом на формування певних психологічних характеристик особистості. Зокрема, доведено, що чоловікам, які займаються спортивною діяльністю, більшою мірою характерна виразність сили процесів збудження, що визначають ступінь активності, енергії та працездатності [6]. Існують окремі дослідження, у яких указано на істотні відмінності вікової динаміки психологічних показників у спортсменів різної статі. У цьому разі вчені акцентують на тому, що з віком у спортсменів різної статі відмінності стають менш помітними, натомість у тих, хто не займається спортом, - зростають $[6 ; 8 ; 12$; $16 ; 22 ; 23]$

Отже, ми погоджуємося з думкою науковців, що основою гендерної ідентичності є біологічна стать людини $[5 ; 8]$. Особистість сприймає, засвоює, конструює власну гендерну ідентичність на основі належності до чоловічої чи жіночої статі. Надбудовою до біологічного заснування гендерної ідентичності $\epsilon$ інтериоризовані психологічні риси: маскулінність, фемінінність чи андрогінність, - що формуються відповідно до соціокультурних норм суспільства. Фізична культура й спорт як інститут соціалізації є однією з високоспеціалізованих сфер діяльності людини, що здатна формувати гендерні якості особистості, оскільки саме в діяльності, у тому числі спортивній, особистість формується й проявляється [12]. Тому отримані результати нашого дослідження дали підставу підтвердити певну думку науковців про вплив занять спортом на формування маскулінних рис характеру (більшою мірою в представниць жіночої статі) $[2 ; 6 ; 8 ; 16 ; 22]$. Також результати нашого дослідження збігаються 3 результатами досліджень, проведених зарубіжними вченими A.M. Maers, H. M.Lips., S. Spence, R. Helmrich, які свідчать, що дівчата, які займаються спортом, чудово поєднують у собі низку маскулінних якостей, маючи високий рівень фемінінності [20;21;22; 23; 25].

На нашу думку, фізичне виховання володіє величезним потенціалом емоційного та фізичного впливу на формування гендерної ідентичності учнів і їхнього уявлення про жіночність та мужність. Це безпосередньо може впливати на формування життєвих ціннісних орієнтацій школярів загалом, у тому числі на формування цінностей у сфері фізичної культури.

Висновки та перспективи подальших досліджень. Отримані в результаті проведеного дослідження дані дали підставу зробити висновок про те, що заняття спортом сприяють розвитку певних маскулінних рис характеру. Причому більшою мірою це стосується представниць жіночої статі. Дівчата, які активно залучені до спортивної діяльності, є більш маскулінні за тих, які спортом не займаються. Їх вирізняє вища самооцінка низки якостей, які зазвичай асоціюються 3 мужністю, розвиненою волею й більш високою агресивністю. У спортсменів чоловічої статі менше проявляються фемінінні характеристики особистості. Рівень прояву емпатії до оточення та комунікативні характеристики більш виражені в дівчат і юнаків, які займаються спортом. Аналітичний аналіз отриманих 
даних дав нам підставу також виділити індивідуальні психологічні характеристики особистості, які більше притаманні школярам, котрі не займаються спортом. Для юнаків це показники, які практично не були відзначені: ніжність, теплота, щедрість, співчуття, турбота про людей, м'якість, жіночність, здатність допомагати, уміння поступатися, спроможність співчувати, розуміння інших, уміння втішати, життєрадісність, надійність, віра в себе, прямота. Для дівчат це такі психологічні характеристики, як довірливість, уміння дружити, любов до дітей і спокій (були відзначені лише в 5,8 \% респонденток). $11 \%$ спортсменок проігнорували вищезазначені якості. Тільки 5,88 \% дівчат, котрі займаються спортом, відзначили «нелюбов до лайок», натомість 17,65 \% вважають для себе цю характеристику абсолютно прийнятною. Лише 5,8 \% дівчат-спортсменок відзначили в собі риси характеру, які вчені відносять здебільшого до фемінінних характеристик особистості: сором'язливість,потайність, відданість. 29,41 \% спортсменок не помічають у собі таких якостей. За результатами нашого дослідження виявлено, що серед тхеквондистів тенденція до маскулінності більш властива дівчатам, ніж юнакам.

Отже, використання гендерного підходу в теорії й методиці фізичного виховання надає широкі можливості для переосмислення концепцій фізичного виховання, але разом із тим потрібно усвідомлювати, що це не просто нова теорія, а теорія, прийняття якої передбачає зміну ціннісних орієнтирів і перегляд багатьох усталених уявлень щодо досліджуваної теми. Тому подальші наші дослідження будуть стосуватися вивчення впливу психологічної статі (маскулінність, фемінінність, андрогінність) на мотиваційні пріоритети у сфері фізичної культури й спорту в школярів різних вікових груп.

\section{Джерела та література}

1. Азарова Е. О. Влияние культуры на формирование и изменение моральных гендерных стереотипов. Российские женщины и европейская культура: материалы науч. конф. Санкт-Петербург, 2001. С. 213-219.

2. Арканцева Т. А. Отношение родителей и детей в гендерном измерении: учеб. пособие. Москва: НОУ ВПО Моск. психол.-соц. ин-т, 2011.70 с.

3. Базарний В. Ф. О трагических последствиях смешанного воспитания и обучения в школах. Образование и здоровье учащихся: материалы Всерос. форума с междунар. участием. Ч. III. Москва: 4Д «Класс -С», 2005. C. 29-37.

4. Бем С. Линзы гендера: трансформация взглядов на проблему неравенства полов/[пер. с англ.]. Москва: Рос. полит. энцикл. (РОССПЭН), 2004. 336 с.

5. Грошев И. В. Психофизиологические различия мужчин и женщин. Москва: Изд-во Моск. психол.-соц. инта; Воронеж: Изд-во НПО «МОДЕК», 2005. 464 с.

6. Дамадаева А. С. Специфика гендерной дифференциации личности в спорте. Журнал «Ученые записки университета имени П. Ф. Лесгафта». 2010. № 10 (68).

7. Дульмухаметова Г. Ф. Педагогические условия половой дифференциации обучения младших школьников: дис. ... канд. пед. наук. Казань, 2011.

8. Ильин Е. П. Пол и гендер. Питер, 2010. 686 с.

9. Клецина ИС. Психология гендерних отношений: теория и практика. Санкт-Петербург: Алтейя, 2004. $408 \mathrm{c}$.

10. Коган В. Є. Когнітивні й емоційні аспекти гендерних установок у дітей 3-7 років. Питання психології. 2000. № 2. C. 65-69.

11. Круцевич Т. Ю., Марченко О.Ю. Проблемы гендерного подхода в физическом воспитании. Materialete Congresului Ştiinţific Internaţional «SPORT. OLIMPISMSM. SĂNĂTATE VOLUMUL» Chişină, Republica Moldova, 5-8 octobrie 2016. C. 233-240.

12. Марченко О. Ю. Теоретико-методологічні основи гендерного підходу до формування аксіологічної значущості фізичної культури школярів: монографія. Переяслав-Хмельницький, 2018. 292 с.

13. Марченко О. Ю. Особливості гендерної ідентичності у школярів різного віку. Педагогіка, психологія та медико-біологічні проблеми фізичного виховання і спорту. 2014. №1. С. 37-41.

14. Москаленко Н. В. Інноваційні технології у фізичному вихованні школярів: навч. посіб. для студентів вищ. навч. закл. Дніпропетровськ: Інновація. 2014. 332 с.

15. Пангелова Н. Є. Теоретико-методичні засади формування гармонійно розвиненої особистості дитини дошкільного віку в процесі фізичного виховання: [дисертація]. Київ: Нац. ун-т фіз. вих. і спорту України, 2014. $445 \mathrm{c}$.

16. Родоманова С. С. Социально-педагогические проблемы гендерных отношений в спорте: диссертация. Санкт-Петербург: Санкт-Петерб. гос. ун-т физ. культуры, 2007. 243 с.

17. Рымарев Н. Ю. Личностные особенности подростков с различной гендерной идентичностью: дис. ... канд. психол. наук: спец. 19.00.01. Краснодар, 2006. 
18. Слепова Л. Н., Хаирова Т. Н., Дижонова Л. Б. Гендерный подход к физическому воспитанию студентов. Современные наукоемкие технологии. 2010. № 5. С. 129-130.

19. Тарасенко Л. В. Гендерный подход в физическом воспитании как фактор оздоровления младших школьников: автореф. дис. ... канд. наук: спец.: 13.00.04 «Теория». Москва: РГБ, 2007. 18 с.

20. Томенко О. А, Бондар А. С. Особливості залучення дітей та молоді до фізкультурно-оздоровчої діяльності у сучасних умовах. Молодий вчений. 2018. (11). 69-73.

21. Abraham W. T., Gramer R. E., Fernandes A. M,. Mahler E. Infidelity, race and gender. An evolutionary on asymmetries in subjective distress to violations - of - trust [Infidelity, race and gender. An evolutionary on asymmetries in subjective distress to violations - of - trust]. Current Psychology, winter. 2001-2002. Vol. 2. № 4. P. 337-348.

22. Meyer J. D., Schmidt A. M. Gender political in four contexts: Political interest and values among junior high school students in China, Japan, Mexico and United States. Social Science jornal. 2004. №. 41 (3). P. $393-407$.

23. Myers A. M., Lips H. M. Participation in competitive amateur sports as a function of psychological and raging. Sox Roles. 1978. V. 4. P. 571-578.

24. Scott S. Gender: a useful category of historical analisis. The American Historical Review. 1986. Vol. 91. № 5. P. 10-67.

25. Spence S., Helmrich R. Androgyny vs. gender schema: A comment of Bem's gender shame theory. Psychological Review. 1981. V. 88. P. 365-368.

26. Gonsoulin M. Women's Rights and Women's Rites. Religion at the Historical Root of Gender Stratification [Women's Rights and Women's Rites. Religion at the Historical Root of Gender Stratification]. Electronic jornal of Sociology. 2005. P 329-334.

27. Oliver K. L. Kirk D. Girls, gender and physical, education: an activist approach (routledge studies in physical education and youth sport). Routledge. 2015. $136 \mathrm{p}$.

28. Pawlowski C. S., Ergler C., Tjørnhø j-Thomsen T., Schipperijn J.et al. 'Like a soccer camp for boys'. A qualitative exploration of gendered activity patterns in childrens self-organized play during school recess. European Physical Education Review. 2015. Vol. 21. P. 275-291.

29. Slingerland M., Haerens L., Cardon G., Borghouts L. Differences in perceived competence and physical activity levels during single-gender modified basketball game play in middle school physical education. European Physical Education Review. 2014. Vol. 20. P. 20-35.

\section{References}

1. Azarova, E. O. (2001). Vliyanie kultury na formirovanie i izmenenie moralnyh gendernyh stereotipov [The influence of culture on the formation and change of moral gender stereotypes]. Rossijskie zhenshiny $i$ evropejskaya kultura. Mat. nauch. konf., 213-219.

2. Arkanceva, T. A. (2011). Otnoshenie roditelej i detej v gendernom izmerenii [The relationship of parents and children in the gender dimension]: uchebnoe posobie. Moskva: NOU VPO Moskovskij psihologo-socialnyj institut, 70.

3. Bazarnyj, V. F. (2005). O tragicheskih posledstviyah smeshannogo vospitaniya i obucheniya v shkolah [About the tragic consequences of mixed education and education at schools]. Obrazovanie $i$ zdorove uchashihsya: Materialy Vserossijskogo Foruma s mezhdunarodnym uchastiem. Chast III. Moskva, 29-37.

4. Bem, S. (2004). Linzy gendera: Transformaciya vzglyadov na problemu neravenstva polov [Gender Lenses: transforming views on inequality of sexes]. Moskva: «Rossijskaya politicheskaya enciklopediya» (ROSSPEN), 336.

5. Groshev, I. V. (2005). Psihofiziologicheskie razlichiya muzhchin i zhenshin [Psychophysiological differences between men and women]. Moskva: Izdatelstvo Moskovskogo psihologo-socialnogo instituta; Voronezh: Izdatelstvo NPO «MODEK», 464.

6. Damadaeva, A. S. (2010). Specifika gendernoj differenciacii lichnosti $v$ sporte [The specifics of gender differentiation of personality in sports]. Uchenye zapiski universiteta imeni P. F. Lesgafta, no. 10 (68).

7. Dulmuhametova, G. F. (2011). Pedagogicheskie usloviya polovoj differenciacii obucheniya mladshih shkolnikov [Pedagogical conditions of sexual differentiation of education of primary school students.]. Dissertaciya na soiskanie uchenoj stepeni kandidata pedagogicheskih nauk, Kazan.

8. Ilin, E. P. (2010). Pol i gender [Sex and gender]. Piter, 686.

9. Klecina, I. S. (2004). Psihologiya gendernih otnoshenij: teoriya i praktika [Psychology of gender relations: theory and practice]. Sankt-Peterburg: Altejya, 408.

10. Kohan, V. Ye. (2000). Kohnityvni y emotsiini aspekty hendernykh ustanovok u ditei 3-7 rokiv [Cognitive and emotional aspects of gender attitudes in children of 3-7 years old]. Pytannia psykholohii, no. 2, 65-69.

11. Krutsevych, T. Yu., Marchenko, O. Iu. (2016). Problemy hendernoho podkhoda v fyzycheskom vospytanyy [Problems of a gender approach in physical education.].. Materialete Congresului Ştiinţific Internaţional «SPORT. OLIMPISMSM. SĂNĂTATE VOLUMUL» Chişină, Republica Moldova, 5-8 octobrie, 233-240.

12. Marchenko, O. Iu. (2018). Teoretyko-metodolohichni osnovy hendernoho pidkhodu do formuvannia aksiolohichnoi znachushchosti fizychnoi kultury shkoliariv: monohrafiia [Theoretical and methodological foundations of the gender approach to the formation of axiological significance of physical culture of schoolchildren]. Pereiaslav-Khmelnytskyi, 292. 
13. Marchenko, O. Yu. (2014). Osoblyvosti hendernoi identychnosti u shkoliariv riznoho viku [Features of gender identity in students of all ages.]. Pedahohika, psykholohiia ta medyko-biolohichni problemy fizychnoho vykhovannia i sportu, no. 1, 37-41.

14. Moskalenko, N. V. (2014). Innovatsiini tekhnolohii u fizychnomu vykhovanni shkoliariv [Innovative technologies in physical education of schoolchildren] navch. posibnyk dlia stud. vyshch. navch. Zakladiv, Dnipropetrovsk: Innovatsiia, 332.

15. Panhelova, N. Ye. (2014). Teoretyko-metodychni zasady formuvannia harmoniino rozvynenoi osobystosti dytyny doshkilnoho viku v protsesi fizychnoho vykhovannia [Theoretical and methodological foundations of forming a harmoniously developed personality of a preschool child in the process of physical education]. Dysertatsiia, Kyiv: Natsionalnyi universytet fizychnoho vykhovannia i sportu Ukrainy, 445.

16. Rodomanova, S. S. (2007). Socialno-pedagogicheskie problemy gendernyh otnoshenij v sporte [Sociopedagogical problems of gender relations in sports.]. Dissertaciya. Sankt-Peterburg: Sankt-Peterburgskij gosudarstvennyj universitet fizicheskoj kultury, 243.

17. Rymarev, N. Yu. (2006). Lichnostnye osobennosti podrostkov s razlichnoj gendernoj identichnostyu [Personal characteristics of adolescents with different gender identities.]. Dis. kand. psih. nauk, spec. 19.00.01, Krasnodar.

18. Slepova, L. N., Hairova, T. N., Dizhonova, L. B. (2010). Gendernyj podhod k fizicheskomu vospitaniyu studentov [Gender approach to physical education of students]. Sovremennye naukoemkie tehnologii, no. 5, $129-130$.

19. Tarasenko, L. V. (2007). Gendernyj podhod v fizicheskom vospitanii kak faktor ozdorovleniya mladshih shkolnikov [Gender approach in physical education as a factor in the recovery of primary school children]: avtoref. dis. na soisk. nauchn. step. kand. nauk: spec.: 13.00.04 «Teoriya». Moskva: RGB, 18.

20. Tomenko, O. A, Bondar, A. S. (2018). Osoblyvosti zaluchennia ditei ta molodi do fizkulturno-ozdorovchoi diialnosti u suchasnykh umovakh [Features of involvement of children and young people in physical and recreational activity in modern conditions]. Molodyi vchenyi, 69-73.

21. Abraham W. T., Gramer R. E., Fernandes A. M,. Mahler E. Infidelity, race and gender. An evolutionary on asymmetries in subjective distress to violations - of - trust [Infidelity, race and gender. An evolutionary on asymmetries in subjective distress to violations - of - trust]. Current Psychology, winter, 2001-2002, Vol. 2, № 4, P. 337-348.

22. Meyer J. D., Schmidt A. M. Gender political in four contexts: Political interest and values among junior high school students in China, Japan, Mexico and United States. Social Science jornal, 2004, 41 (3), 393-407.

23. Myers A. M., Lips H. M. Participation in competitive amateur sports as a function of psychological and raging. Sox Roles, 1978, vol. 4, 571-578.

24. Scott S. Gender: a useful category of historical analisis. The American Historical Review, 1986, Vol. 91, № 5, $10-67$.

25. Spence S., Helmrich R. Androgyny vs. gender schema: A comment of Bem's gender shame theory. Psychological Review, 1981, Vol. 88, 365-368.

26. Gonsoulin M. Women's Rights and Women's Rites. Religion at the Historical Root of Gender Stratification [Women's Rights and Women's Rites. Religion at the Historical Root of Gender Stratification]. Electronic jornal of Sociology, 2005, 329-334.

27. Oliver K. L. Kirk D. Girls, gender and physical, education: an activist approach (routledge studies in physical education and youth sport). Routledge, 2015, $136 \mathrm{p}$.

28. Pawlowski C. S., Ergler C., Tjørnhø j-Thomsen T., Schipperijn J.et al. 'Like a soccer camp for boys'. A qualitative exploration of gendered activity patterns in childrens self-organized play during school recess. European Physical Education Review, 2015, Vol. 21, 275-291.

29. Slingerland M., Haerens L., Cardon G., Borghouts L. Differences in perceived competence and physical activity levels during single-gender modified basketball game play in middle school physical education. European Physical Education Review, 2014, Vol. 20, 20-35.

Стаття надійшла до редакції 24.02.2020 р. 